Article

\title{
Application of Tea Polyphenols and Their Effects on Ultrafiltration Effluent Disinfection and Microbial Risk
}

\author{
Cuimin Feng ${ }^{1,2, *}$, Tong Wei ${ }^{1,2}$, Shan Qing ${ }^{3}$, Fang Han ${ }^{1,2}$ and Xingcheng Tao ${ }^{1,2}$ \\ 1 Key Laboratory of Urban Stormwater System and Water Environment, Beijing University of Civil \\ Engineering and Architecture, Ministry of Education, Beijing 100044, China; 13180036570@163.com (T.W.); \\ hanfang@bucea.edu.cn (F.H.); bucea111277490@163.com (X.T.) \\ 2 National Demonstration Center for Experimental Water Environment Education, Beijing University of Civil \\ Engineering and Architecture, Beijing 100044, China \\ 3 Infrastructure Division, Chinese National Academy of Arts, Beijing 100012, China; m15801606865@163.com \\ * Correspondence: feng-cuimin@sohu.com; Tel.: +86-13-611379073
}

check for updates

Citation: Feng, C.; Wei, T.; Qing, S. Han, F.; Tao, X. Application of Tea Polyphenols and Their Effects on Ultrafiltration Effluent Disinfection and Microbial Risk. Water 2021, 13, 2559. https://doi.org/10.3390/ w13182559

Academic Editor: Bing-Jie Ni

Received: 5 September 2021

Accepted: 15 September 2021

Published: 17 September 2021

Publisher's Note: MDPI stays neutral with regard to jurisdictional claims in published maps and institutional affiliations.

Copyright: (c) 2021 by the authors. Licensee MDPI, Basel, Switzerland. This article is an open access article distributed under the terms and conditions of the Creative Commons Attribution (CC BY) license (https:/ / creativecommons.org/licenses/by/ $4.0 /$ )

\begin{abstract}
To reduce the risk of by-products from traditional disinfection technology and to ensure safe water quality, tea polyphenols (TP) were used as disinfectants after the ultrafiltration (UF) process. The disinfectant effect of TP was tested on the total number of bacteria and changes in bacterial community structure, and pathogen virulence factors were detected by Illumina's highthroughput sequencing technology. The results showed that the recommended dosage of TP for water treatment after UF was $5 \mathrm{mg} / \mathrm{L}$, which can effectively inhibit bacterial growth and maintain the disinfectant effect for up to $48 \mathrm{~h}$ later. In the disinfection process, the degradation of the tea polyphenols concentration was fitted to the equation of the second order reaction kinetics. The lower the initial concentration and the higher the reaction temperature, the faster the TP decay. The metagenomic analysis of the microorganisms indicated that disinfection with tea polyphenols reduced the diversity of microorganisms in the water and altered the structure of the bacterial community. The existence of tea polyphenols also significantly inhibited the growth of potential common Gram-negative pathogens, especially Mycobacterium. TP disinfectant can also reduce the diversity and abundance of pathogenic bacterial virulence factors and improve biological safety in drinking water.
\end{abstract}

Keywords: tea polyphenols; disinfection; pathogenic bacteria; risks; virulence factors

\section{Introduction}

As a necessity of human life, the quality of drinking water affects human health. Therefore, disinfection of drinking water has attracted great attention at home and abroad. Currently, chlorine, chlorine dioxide, ultraviolet and ozone are commonly used as drinking water disinfectants. Its applications have the following characteristics: disinfection with chlorine contains an unpleasant taste and smell [1] and produces toxic by-products [2] Disinfection with chlorine dioxide has the advantages of small-dosage, fast-action and highsterilization rate, but its cost is high, the operation is complex in the process of preparation and use, leakage and explosion are easy to occur [3], and secondary carcinogens will be produced in the disinfection process [4]. Although ultraviolet disinfection has the advantages of a fast sterilization effect, no chemical addition, no formation of disinfection by-products, and cost savings [5], it does not have continuous sterilization capability, resulting in secondary pollution of drinking water in the process of transport pipes [6]. Ozone disinfection is highly efficient and can quickly kill bacteria and viruses in water without causing secondary pollution [7]. However, ozone lacks sustainable sterilization capability and has high cost, which is limited by location. Facing the main needs of the country in strengthening the guarantee of safe drinking water and improving water quality, it is urgent to study green and efficient treatment of drinking water. As a renewable green 
resource, plant polyphenols have caught attention. Plant polyphenols are the secondary metabolites of plants. They are rich in reserves and derive from green sources. A large number of scientific studies have shown that plant polyphenols have antioxidant and other biological activities and physiological functions. The broad-spectrum antibacterial activity of plant polyphenols (including inhibition of filamentous fungi, bacteria and viruses) is the most important embodiment of its biological activity. Through the study of different plant polyphenol extracts, it is found that a variety of plant polyphenols can inhibit microbial growth. At present, the Bacteriostasis of plant polyphenols is mostly used in food, medicine, and other industries, and the research in the field of drinking water is still in the stage of laboratory exploration. The total number of bacteria in raw water is the key factor affecting the dosage of plant polyphenol disinfection, the time to reach the standard, and the disinfection duration. The higher the total number of bacteria in raw water, the greater the dosage of plant polyphenol required and the longer the time to reach the standard. For emergency water using natural water as a direct source, the contact time of plant polyphenols as disinfectant is long. When the dosage is $0.3 \mathrm{~g} / \mathrm{L}$, contact with water for more than $8 \mathrm{~h}$ can make the total number of bacteria reach the drinking standard. For the general pipe network, the water disinfected with plant polyphenols can maintain the total number of bacteria within 3 days without exceeding the standard, and there is no need to supplement chlorine [8]. Based on the extensive antibacterial activity of plant polyphenols, Cuimin Feng [8] and other researchers respectively added three types of plant polyphenols to the filter effluent of waterworks. The test showed that tea polyphenols (TP) had the best disinfection effect and the best disinfection sustainability.

As a type of plant polyphenols, tea polyphenols derive from green environmental protection, have mild performance, are non-toxic and harmless to the human body, and have a health care effect. It is a green and healthy natural bacteriostatic agent extracted from tea. It can have a good disinfection effect and disinfection durability when applied to drinking water disinfection treatment [9]. Therefore, it can be used for emergency and conventional disinfection of drinking water, showing durability and promising results [9-12]. Cuimin Feng et al. [9] and Wanxia Fu et al. [10] found that for emergency drinking water in rivers, the tea polyphenols dosage was $300 \mathrm{mg} / \mathrm{L}$ for $1 \mathrm{~h}$; for emergency drinking water in reservoirs, the dosage was reduced to $50 \mathrm{mg} / \mathrm{L}$ for $30 \mathrm{~min}$, which can meet the requirements [13]. The application of tea polyphenols in conventional water treatment plants as auxiliary disinfectants, replacing the use of chlorine together with decontamination by UV or ozone, may reduce the by-products generated from these treatments and improve the chemical safety of drinking water [13-15].

Currently, ultrafiltration membrane technology has been gradually applied in the renovation and expansion projects of water treatment plants [16-18]. This process achieves turbidity removal rates of greater than $95 \%$, with the effluent turbidity being stable and basically unaffected by the turbidity of the influent water [16-19]. However, due to the individual growth and extrusion deformation of microorganisms in the ultrafiltration process, biological leakage or inevitable post membrane pollution will occur [20-22], and it is necessary to combine disinfection technology to ensure the biological safety of drinking water. Taking advantage of the ultrafiltration process, tea polyphenols can be considered instead of chlorine or chloride disinfection to further enhance the biosafety of the effluent and reduce the risk of disinfection by-products.

One way to assess the effect of disinfection is to estimate the total number of colonies. However, this assessment does not fully reflect the number of all microorganisms in the water. According to the research, the number of microorganisms that can generate colonies in natural water is only about $1 \%$, which means that if the total number of colonies per $\mathrm{ml}$ of water is $100 \mathrm{UFC}$, there can be around $10^{4}$ microorganisms present [16]. Metagenomics establishes a macrogenomic library by extracting all the genetic material of microorganisms from water samples to perform multidimensional assessments of species, abundance, and metabolism of microorganisms. This technique has advantages such as good coverage and detection of microorganisms, including at low concentrations [23], 
which is of great importance for the detection of pathogens [24]. Based on the metagenomic technique, we can also obtain information about the pathogen, its composition, function, pathogenic mechanism and information about the genome of virulence factors, comparing it with the database in order to evaluate the control effect of disinfectants on hazardous microorganisms in water.

The conventional treatment process of waterworks effluent after filter was treated with an ultrafiltration membrane $0.01 \mu \mathrm{m}(100 \mathrm{kDa})$, used as raw water for disinfection tests, and the effect of the disinfection of the ultrafiltration effluent was studied to control the length of microbial regeneration. Combined with the microbial community structure and pathogen risk analysis, the biosafety of disinfection with tea polyphenols in the effluent from the ultrafiltration process of hydroelectric plants was explored in order to establish a theoretical basis for improving the quality and safety of drinking water.

\section{Experimental Materials and Methods}

\subsection{Experimental Materials}

Tea polyphenols were purchased from Anhui Red Star Pharmaceutical Co., Ltd. as green tea extract with a purity of more than $98.0 \%$ (AR98.0\%).

The test raw water was taken from a conventional treatment process water plant after the filtration tank and filtered through a $0.01 \mu \mathrm{m}(100 \mathrm{kDa})$ ultrafiltration membrane. Membrane filtration uses water passing through the membrane to remove microbial particles such as bacteria and viruses, which are retained on the surface or inside the membrane. Viruses are the smallest of the disease-causing microorganisms in water, ranging in size from 0.02 to $0.45 \mu \mathrm{m}$. Pore size of $0.01 \mu \mathrm{m}$ drinking water ultrafiltration technology can be used to effectively remove pathogenic microorganisms, including viruses. The raw water quality test is shown in Table 1.

Table 1. Raw water quality.

\begin{tabular}{|c|c|c|c|}
\hline Parameter & Values & Instruments & Methods \\
\hline Chroma (degree) & $1 \pm 1$ & $\begin{array}{l}\text { PFXi-995 High Precision Automatic } \\
\text { Colorimeter }\end{array}$ & \\
\hline $\begin{array}{l}\text { Turbidity (NTU) } \\
\text { SS (mg/L) }\end{array}$ & $\begin{array}{c}0.1 \\
0.16\end{array}$ & HACH-2100AN Turbidity Meter & \\
\hline $\mathrm{UV}_{254}(1 / \mathrm{cm})$ & $0.013 \pm 0.002$ & $\begin{array}{c}\text { DR6000 (HACH Instrument } \\
\text { Corporation) }\end{array}$ & Direct Reading \\
\hline TOC (mg/L) & $0.90 \pm 0.07$ & $\begin{array}{c}\text { Shimadzu TOC-L Organic Carbon } \\
\text { Analyzer }\end{array}$ & $\begin{array}{c}\text { High Temperature Catalytic } \\
\text { Combustion }\end{array}$ \\
\hline $\mathrm{NO}_{3}-\mathrm{N}(\mathrm{mg} / \mathrm{L})$ & $0.7 \pm 0.2$ & DR6000 UV Spectrophotometers & $\begin{array}{l}\text { Ultraviolet } \\
\text { Spectrophotometry }\end{array}$ \\
\hline $\mathrm{NH}_{4}{ }^{+}-\mathrm{N}(\mathrm{mg} / \mathrm{L})$ & $0.06 \pm 0.01$ & DR6000 UV Spectrophotometers & Salicylic acid method \\
\hline Total phosphorus (mg/L) & $0.69 \pm 0.04$ & DR6000 UV Spectrophotometers & $\begin{array}{l}\text { Digestive-Ascorbic Acid } \\
\text { Method }\end{array}$ \\
\hline Total number of bacteria $(\mathrm{CFU} / \mathrm{mL})$ & $2 \pm 2$ & & Plate Counting \\
\hline Total Coliforms (CFU/100 mL) & 0 & & Multi-tubular fermentation \\
\hline Escherichia coli (CFU/100 mL) & 0 & & \\
\hline $\mathrm{pH}$ & $7.7 \pm 0.2$ & $\begin{array}{c}\text { FiveGo-Single Channel Portable } \mathrm{pH} \\
\text { Meter }\end{array}$ & \\
\hline Dissolved oxygen (mg/L) & $8.54-9.38$ & & Iodometric method \\
\hline
\end{tabular}

The flat ultrafiltration membrane filtration test device used in the test is shown in Figure 1. The device consists of two parts: nitrogen cylinder and ultrafiltration cup (Merck group, UFSC05001, $50 \mathrm{~mL}$ ). The transmembrane pressure required by the ultrafiltration device is provided by the nitrogen cylinder, and the constant transmembrane pressure difference is $0.10 \mathrm{MPa}$. 

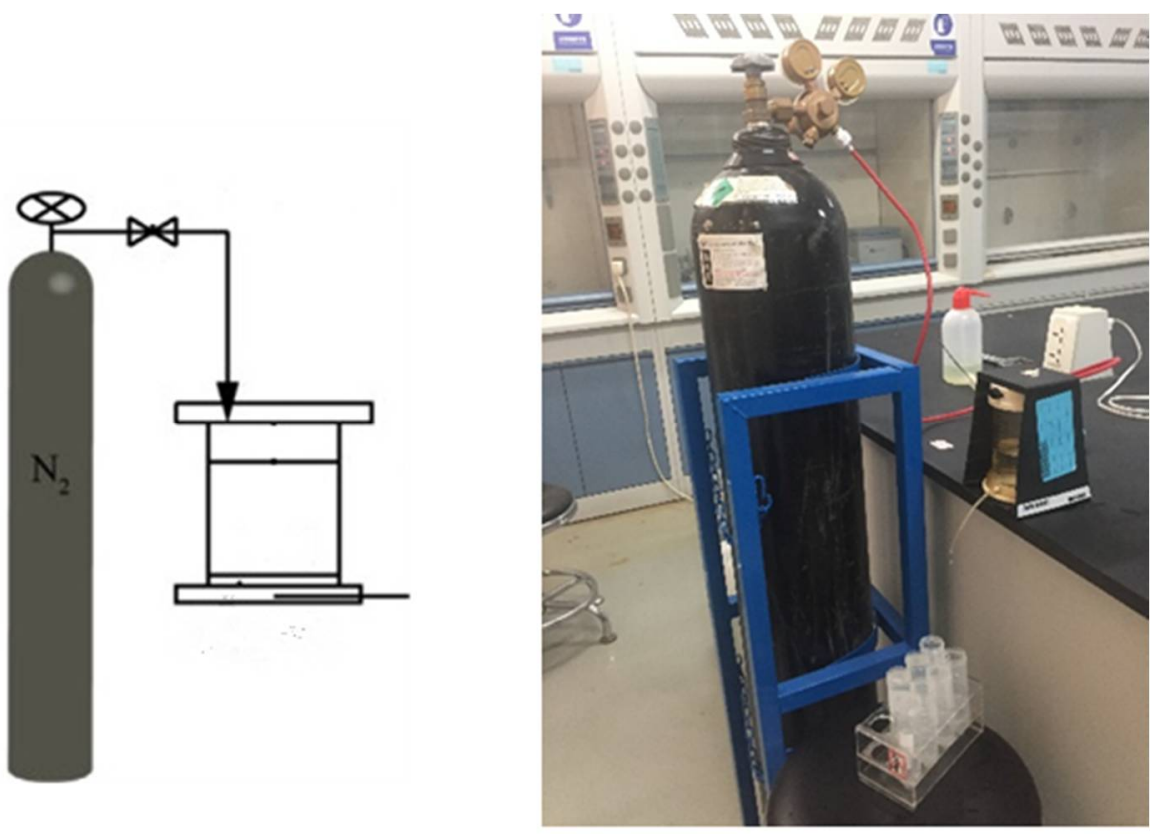

Figure 1. The device UF membrane filtration.

The ultrafiltration membrane used in the test was purchased from Merck \& Co Inc. the material was regenerated cellulose (RC), the operation mode was immersion, the cutting molecular weight was $100 \mathrm{kDa}$, the filtration area was $41.8 \mathrm{~cm}^{2}$ and the diameter was $76 \mathrm{~mm}$.

\subsection{Experimental Design}

(1) Disinfection test. Tea polyphenols were added to raw water at different gradient concentrations from 0 to $10.0 \mathrm{mg} / \mathrm{L}$ in a unit of $2.5 \mathrm{mg} / \mathrm{L}$. The water temperature was adjusted to $10{ }^{\circ} \mathrm{C}$. Samples were detected every $6 \mathrm{~h}$ for different times ( 0 to $48 \mathrm{~h}$ of treatment) to investigate the ideal dosage of tea polyphenols;

(2) Factors that attenuate the tea polyphenols dose efficiency. Initial dosage amounts of tea polyphenols were 5.0,7.5, and $10.0 \mathrm{mg} / \mathrm{L}$. Water temperatures were adjusted to 4,10 , and $20^{\circ} \mathrm{C}$. The concentration of tea polyphenols was measured at $0,12,24,36$, and $48 \mathrm{~h}$ after contact of tea polyphenols with raw water, and the effects of relevant factors in the attenuation of tea polyphenols were investigated;

(3) Microbial community structure and risk microorganism analysis. The best dosage of tea polyphenols was used, and changes in the microbial community structure in the water before and after disinfection were compared. Changes in species and abundance of the pathogenic bacteria virulence factor were analyzed to assess the biosafety of disinfection using tea polyphenols. The raw water sample number was Raw (Table 1), and the disinfected water sample was 5TP with the best dosage of tea polyphenols.

\subsection{Data Detection and Processing}

Total number of colonies: Plate counting method. A volume of $1 \mathrm{~mL}$ tea polyphenols disinfection water samples was evenly distributed on the agar of the prepared petri dish with cover and cultured at $30-37^{\circ} \mathrm{C}$ for $48 \mathrm{~h}$. Then, the total number of bacteria in each $\mathrm{mL}$ of original water sample was counted by the number of bacterial colonies on the plate.

Mass concentration of tea polyphenols: Ferrous tartrate method [14]. The principle is that ferrous tartrate will react with tea polyphenols to form blue purple complex, and the content of tea polyphenols is directly proportional to the color depth. The content of tea polyphenols can be determined by spectrophotometry.

Microbial community structure and bioinformatics analysis: Macro-genome sequencing commissioned by Bioengineering Co. (Shanghai, China). 
Pretreatment of sequencing water samples: $100 \mathrm{~L}$ of water samples disinfected with the ideal dosage of tea polyphenols and $100 \mathrm{~L}$ of raw water were left to stand for $48 \mathrm{~h}$ under the same conditions. Subsequently, the microorganisms in the water samples were retained by a suction filtration device with a $0.01 \mu \mathrm{m}$ pore filter membrane. Genetic material extracted from water enriched microorganisms, before and after with tea polyphenols disinfection, was analyzed by Illumina high-throughput sequencing technology.

Database comparison: Protein sequences from the gene pool were compared to the NR (non-redundant protein sequences, NCBI) database for blastp homology using DIAMOND obtaining information from homologous species. Screening conditions: E value $<1 \times 10^{-5}$, score $>60$; the protein sequences of the gene pool were compared with the setA part in the VFDB (pathogenic bacteria virulence factors) database for BLAST search to obtain information on pathogenic species, composition, function and abundance of virulence factors. Screening criteria: Blast Identity $>20$, Blast eValue $<1 \times 10^{-5.2}$.

\section{Results and Discussion}

\subsection{Disinfection Effect of Tea Polyphenols}

The total count of raw water colonies was $0 \mathrm{CFU} / \mathrm{mL}$, and the microbial growth condition with time under different dosages of tea polyphenols is shown in Figure 2.

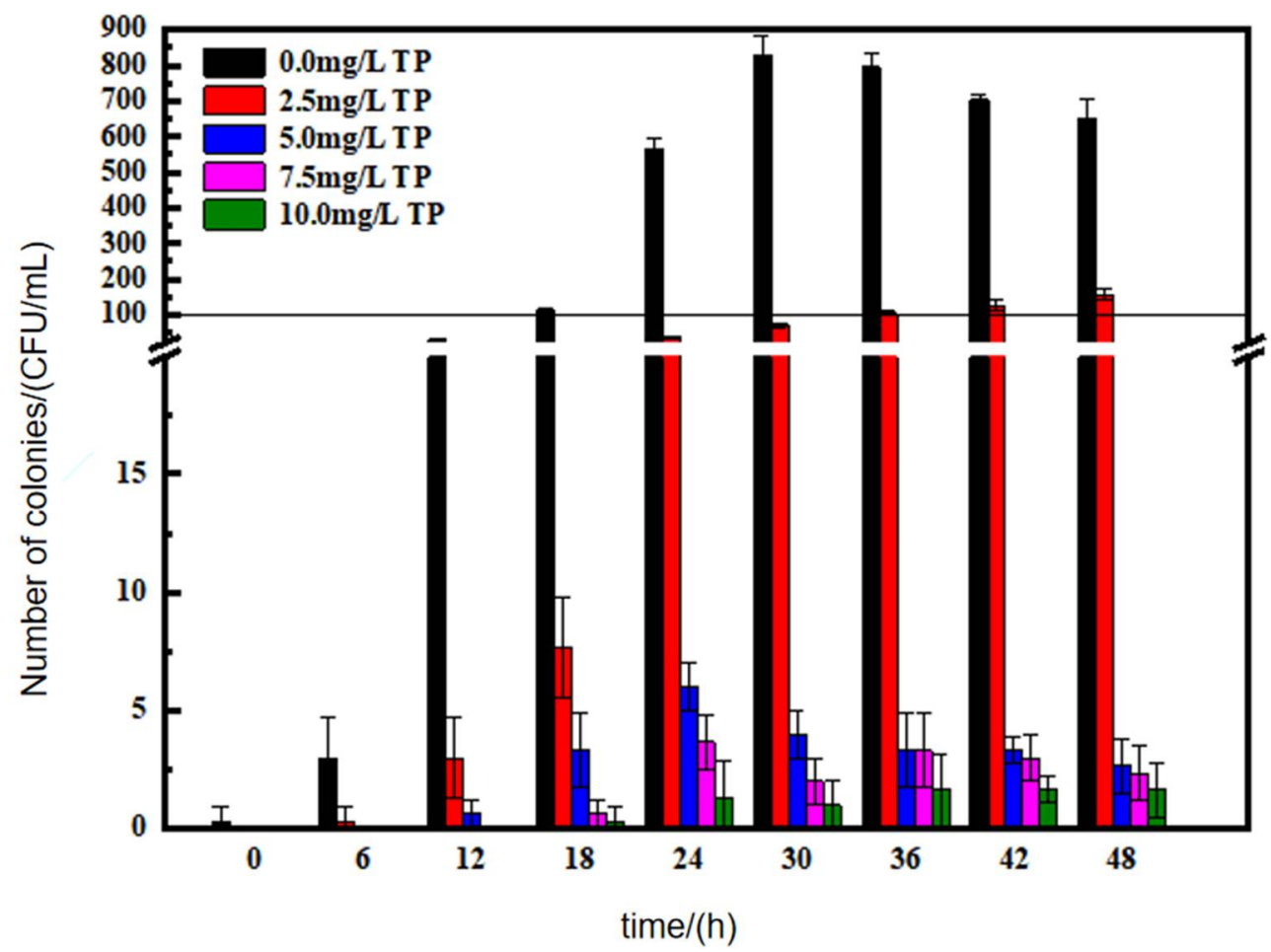

Figure 2. Inhibitory effect of tea polyphenols on bacterial growth at $10^{\circ} \mathrm{C}$.

As seen in Figure 2, tea polyphenols have effective antibacterial properties. The initial dosage of tea polyphenols was $2.5 \mathrm{mg} / \mathrm{L}$; after $12 \mathrm{~h}$, this concentration decreased to $2.11 \mathrm{mg} / \mathrm{L}$, which could control the number of colonies to $3 \pm 2 \mathrm{CFU} / \mathrm{mL}$. Thus, it significantly extended the period of bacterial growth retardation to $18 \mathrm{~h}$, such that after that time, the bacteria grew rapidly. At that time, the concentration of polyphenols in tea was $1.56 \mathrm{mg} / \mathrm{L}$. At $36 \mathrm{~h}$, the total number of colonies was $103 \pm 6 \mathrm{CFU} / \mathrm{mL}$, not meeting the requirements of the drinking water quality standards. When the tea polyphenol dosage was $5.0,7.5$, and $10.0 \mathrm{mg} / \mathrm{L}$, the total number of colonies did not grow. After $24 \mathrm{~h}$, the total number of colonies showed a continuous downward trend, indicating that $5.0 \mathrm{mg} / \mathrm{L}$ can be used as the recommended dosage for disinfection with tea polyphenols, with the total number of colonies in the water being less than $10 \mathrm{CFU} / \mathrm{mL}$ in $48 \mathrm{~h}$. 
The justification for this behavior may be due to the fact that many compounds present in tea, such as hydroxyl-containing phenolic groups, can combine hydrogen with amino or carboxyl groups in protein molecules, and their hydrophobic benzene ring structure can also combine hydrophobically with protein. This multipoint bond between polyphenol and tea protein is one of the important reasons for its bacteriostasis. The antibacterial effect mainly results from the combination of tea polyphenols with proteins from the environment, which affects the use of proteins by microorganisms; In addition, tea polyphenols can also combine with intracellular proteins. Tea polyphenols act with cellular enzyme proteins to reduce enzyme activity. Tea polyphenols combine with membrane proteins to affect the absorption of microbial nutrients, reduce bacterial phosphorus metabolism, and affect the metabolism of bacterial life. There are several effects that inhibit bacterial growth and reproduction [25]. The treatment of ultrafiltration effluent with tea polyphenols as a disinfectant has high efficiency and sustainability.

\subsection{Decline of Tea Polyphenols and Their Influencing Factors}

(1) The effect of initial dosage on the decomposition of tea polyphenols.

When the water temperature reaches 4,10 , and $20^{\circ} \mathrm{C}$, the initial dosage of tea polyphenols is respectively 5.0, 7.5, and $10.0 \mathrm{mg} / \mathrm{L}$, after processing zero, primary or pseudoprimary level, there is the analysis of fit of secondary and tertiary reaction kinetic equation. The decline of tea polyphenols in the disinfection process at a dosage of 5-10 mg/L agrees with the kinetic equation of the second order reaction. The $\mathrm{R}^{2}$ values of regression equation of tea polyphenol concentration were greater than 0.93 . The higher the initial dosage, the slower the attenuation of the tea polyphenols. The same results were observed by Yang Tongtong [13] and Guo Ziyu [14], with the order of the reaction increasing by one order compared to the dose of 10-300 mg/L [13,14,26]. It shows that when the dose of tea polyphenols is $5.0-10.0 \mathrm{mg} / \mathrm{L}$, the effect of the initial concentration on its attenuation is more significant than at the concentration of 10-300 mg/L, as shown in Table 2.

Table 2. Reaction rate equation of tea polyphenol solution in disinfection process.

\begin{tabular}{|c|c|c|c|c|c|c|}
\hline $\begin{array}{c}\text { TP } \\
\operatorname{Dose} /(\mathrm{mg} / \mathrm{L})\end{array}$ & $\begin{array}{c}\text { Water } \\
\text { Temperature } /\left({ }^{\circ} \mathrm{C}\right)\end{array}$ & $\begin{array}{c}\text { Regression } \\
\text { Equation }\end{array}$ & $\mathbf{R}^{2}$ & $\begin{array}{c}\mathrm{k} / \\
\left(\mathrm{L} \cdot(\mathrm{mg} \cdot \mathrm{h})^{-1}\right)\end{array}$ & $\mathbf{t}_{1 / 2} /(\mathbf{h})$ & $\begin{array}{c}\text { Concentration of TP } \\
\text { after } 48 \mathrm{~h}(\mathrm{mg} / \mathrm{L})\end{array}$ \\
\hline \multirow{3}{*}{5.0} & 4 & $y=0.00240 x$ & 0.9934 & $2.400 \times 10^{-3}$ & 76.53 & 3.22 \\
\hline & 10 & $y=0.00460 x$ & 0.9425 & $4.600 \times 10^{-3}$ & 39.93 & 2.11 \\
\hline & 20 & $y=0.00720 x$ & 0.9387 & $7.200 \times 10^{-3}$ & 25.51 & 1.56 \\
\hline \multirow{3}{*}{7.5} & 4 & $y=0.00064 x$ & 0.9688 & $0.643 \times 10^{-3}$ & 202.72 & 6.00 \\
\hline & 10 & $y=0.00128 x$ & 0.9755 & $1.280 \times 10^{-3}$ & 101.90 & 4.89 \\
\hline & 20 & $y=0.00265 x$ & 0.9895 & $2.650 \times 10^{-3}$ & 49.22 & 3.78 \\
\hline \multirow{3}{*}{10.0} & 4 & $y=0.00033 x$ & 0.9712 & $0.327 \times 10^{-3}$ & 292.92 & 8.78 \\
\hline & 10 & $y=0.00062 x$ & 0.9828 & $0.615 \times 10^{-3}$ & 155.63 & 7.67 \\
\hline & 20 & $y=0.00119 x$ & 0.9658 & $1.190 \times 10^{-3}$ & 80.46 & 6.00 \\
\hline
\end{tabular}

(2) The effect of temperature on the decomposition of tea polyphenols.

Because the chemical structure of tea polyphenols is rich in phenolic hydroxyl groups, in the enzymatic oxidation polymerization reaction, these compounds produce o-quinone derivatives under the catalysis of tea polyphenols oxidase, and further polymerize to form dimers and polymers; under nonenzymatic conditions, these compounds can still be oxidized and polymerized under the catalysis of trace metal ions to form dimers and polymers and reactive oxygen radicals [27]. Temperature can affect the oxidation polymerization reaction in the disinfection process through tea polyphenols, which causes them to produce different degrees of attenuation [28]. Studies have shown that the higher the temperature, the faster the tea polyphenols decompose. According to Table 2, the decay rate of tea polyphenols solution at $20^{\circ} \mathrm{C}$ is higher than that at $10^{\circ} \mathrm{C}$, and the lowest at $4{ }^{\circ} \mathrm{C}$. At a dosage of $5.0 \mathrm{mg} / \mathrm{L}$, the reaction rate constant $\mathrm{k}$ of $10{ }^{\circ} \mathrm{C}$ tea polyphenols is 
$4.6 \times 10^{-3} \mathrm{~L} /(\mathrm{mg} \cdot \mathrm{h})$ with a half-life of $39.93 \mathrm{~h}$. A concentration of $2.11 \mathrm{mg} / \mathrm{L}$ after $48 \mathrm{~h}$, which is still higher than $2.0 \mathrm{mg} / \mathrm{L}$, can inhibit bacterial growth and guarantee the total number of colonies at a lower level. While at $20{ }^{\circ} \mathrm{C}$, the reaction rate constant $\mathrm{k}$ increases to $7.2 \times 10^{-3} \mathrm{~L} /(\mathrm{mg} \cdot \mathrm{h})$, and the half-life is reduced to $25.51 \mathrm{~h}$. The concentration of polyphenols in tea is less than $2.0 \mathrm{mg} / \mathrm{L}$ after $48 \mathrm{~h}$, which may pose a threat to the biosafety of water. Therefore, it is advisable to increase the dosage of tea polyphenols in summer and maintain the dosage of tea polyphenols in water to ensure the inhibiting effect on microbial growth.

\subsection{Analysis of the Structure of the Microbial Community in Water after Disinfection with Tea Polyphenols}

Metagenome sequencing yielded a total of $97,166,304$ reads. A total of $377,730 \mathrm{bp}$ of gene number was obtained after data processing by Trimmomatic, splicing assembly by IDBA_UD software and ORF prediction by Prodigal. The Shannon and Simpson indices of the water samples are shown in Table 3. The Shannon and Simpson index of tea polyphenols from the water sample disinfected at 5TP (after $48 \mathrm{~h}$ of reaction between $5 \mathrm{mg} / \mathrm{L}$ of tea polyphenols tea and raw water) were lower than raw water. Thus, it demonstrates that the disinfection process with tea polyphenols will reduce the diversity of microorganisms in the water. This is consistent with the trend toward the effect of chlorine-based disinfectants on the microbial diversity of drinking water [29]. For example, chlorine and chloramines in the drinking water disinfection process reduce the diversity of microorganisms in the system [30-32].

Table 3. Community diversity statistics.

\begin{tabular}{cccccc}
\hline Sample & $\begin{array}{c}\text { Number of } \\
\text { Genes }\end{array}$ & $\begin{array}{c}\text { Total Length of } \\
\text { All Genes/(bp) }\end{array}$ & $\begin{array}{c}\text { Average } \\
\text { Gene } \\
\text { Length/(bp) }\end{array}$ & $\begin{array}{c}\text { Shannon } \\
\text { Index }\end{array}$ & $\begin{array}{c}\text { Simpson } \\
\text { Index }\end{array}$ \\
\hline Raw & 309,360 & $199,399,269$ & 644.55 & 11.13 & $1 \times 10^{-4}$ \\
$5 T P$ & 68,370 & $52,644,429$ & 769.99 & 9.87 & $4 \times 10^{-5}$ \\
\hline
\end{tabular}

Bacteria, archaea, viruses and fungi could be detected in Raw and 5TP, as shown in Table 4. Most sequences are related to the bacterial community, accounting for more than $98 \%$ of the total annotated protein sequences. Therefore, the structure of the bacterial community is the focus of the analysis.

Table 4. Proportion of microbial species at the kingdom level.

\begin{tabular}{ccc}
\hline Pathogenic Microbes & Raw/(\%) & 5TP/(\%) \\
\hline Bacteria & 98.7478 & 99.4904 \\
Archaea & 0.0004 & 0.0017 \\
Viruses & 0.0020 & 0.0017 \\
Fungi & 0.0070 & 0.0014 \\
Else & 1.2428 & 0.5048 \\
\hline
\end{tabular}

At the phylum level, the flora in raw water includes Proteobacteria, Bacteroidetes and Actinobacteria, with percentages of $86.03 \%, 4.73 \%$ and $3.99 \%$ respectively, as shown in Figure 3a. This result is consistent with the research by Zhang [33], who studied the main bacterial groups in effluent water after membrane filtration, albeit with slightly different distribution ratios. Proteobacteria is the absolute dominant group in water after tap water treatment. After disinfection with tea polyphenols, the relative abundance of Proteobacteria increases from $86.03 \%$ to $96.63 \%$, and that of Bacteroidetes and Actinobacteria decreases to less than $0.2 \%$, as shown in Figure $3 a$. 


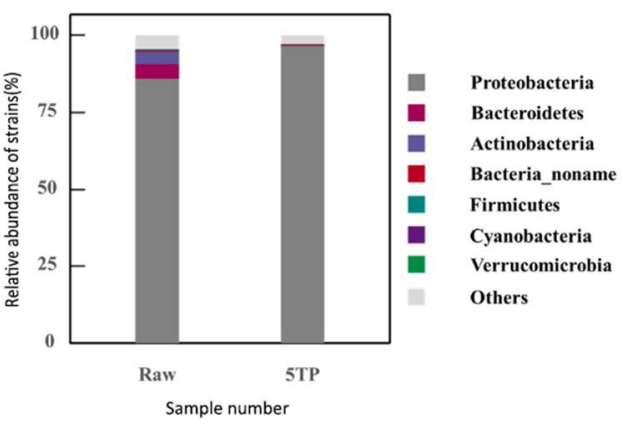

(a) the phylum level

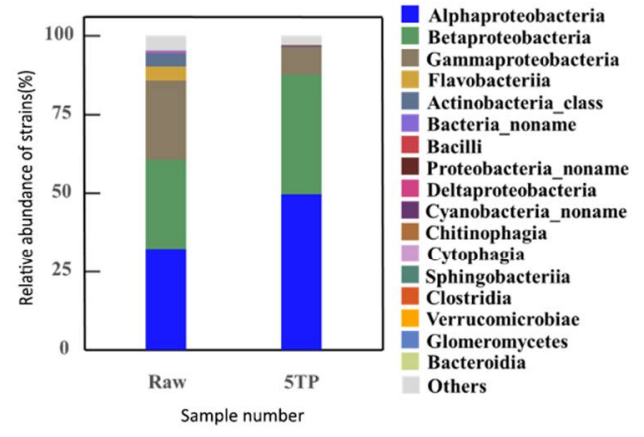

(b) the class level

Figure 3. Histogram of relative abundance at the level of phylum (a) and class classification (b).

At the class level, as shown in Figure 3b, the groups of bacteria in raw water are Alphaproteobacteria, Betaproteobacteria, Gammaproteobacteria, Flavobacteria and Actinobacteria, representing $32.35 \%, 28.32 \%, 25.10 \%, 4.54 \%$ and $3.99 \%$, respectively. The dominant bacterial groups consist of Alphaproteobacteria, Betaproteobacteria and Gammaproteobacteria. After disinfection with tea polyphenols, the proportion of Alphaproteobacteria and Betaproteobacteria increased to $49.74 \%$ and $37.91 \%$, respectively, while the proportion of Gammaproteobacteria decreased to $8.76 \%$. The relative abundance of Flavobacteria and Actinobacteria decreased to $0.03 \%$ and $0.15 \%$, respectively.

At the genus classification level, the heatmap of 39 strains with high relative abundance is shown in Figure 4. The dominant communities in raw water are Sphingobium, Acinetobacter, Pseudomonas, Janthinobacterium, Methylophilus, Flavobacterium and Mycobacterium. After disinfection with tea polyphenols, the dominant population decreased to Sphingobium, Janthinobacterium and Pseudomonas.

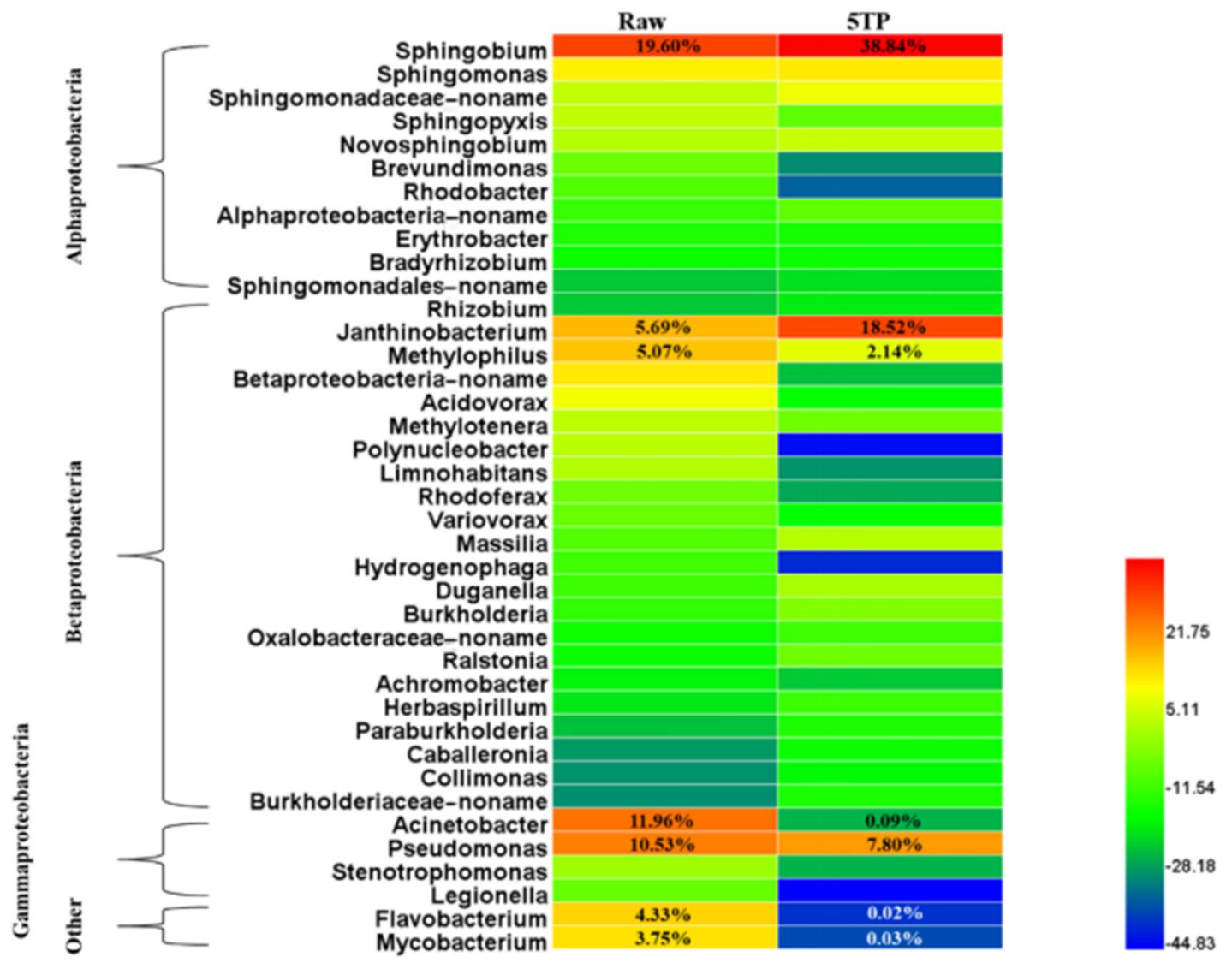

Figure 4. Heatmap of relative abundance at the genus level. 
After disinfection with tea polyphenols, the relative abundance of Sphingobium increased from $19.60 \%$ to $38.84 \%$, which belongs to an important bacterial group that increases the relative abundance of Alphaproteobacteria. Sphingobium can grow in a nutrient-poor environment due to its extensive and efficient metabolic capacity and multifunctional physiological characteristics [34,35]; thus, it is dominant after disinfection with tea polyphenols.

After disinfection with tea polyphenols, the relative abundance of Janthinobacterium increases from $5.69 \%$ to $18.52 \%$. Certain Janthinobacterium bacteria can produce a secondary metabolite, such as Violacein [36], which has been widely shown to have antibacterial and antiviral activity $[37,38]$. This suggests that tea polyphenols promote the growth of colonies that can produce violacein, which exerts antibacterial and bactericidal effects along with secondary metabolites having antibacterial and antiviral activities. Janthinobacterium belong to the phylum Betaproteobacteria and are representative of the groups that increase the relative abundance of the phylum Betaproteobacteria. Conversely, the genus Methylophilus, which also belongs to Betaproteobacteria, is sensitive to disinfection with tea polyphenols, and its relative abundance decreased from $5.07 \%$ to $2.14 \%$. After disinfection with tea polyphenols, the relative abundance of Acinetobacter and Pseudomonas belonging to Gammaproteobacteria, as well as Flavobacterium to Flavobacteria and Mycobacterium to Actinobacteria, decreased significantly. Among them, Pseudomonas represents a relatively high percentage. Most of these bacteria were Gram-negative cocci or bacilli, common in water, and all were conditioned pathogenic bacteria [15,39]. Acinetobacter and Mycobacterium are bacterial pathogens listed in the WHO Guidelines for Drinking Water Quality, and Mycobacterium has strong resistance to disinfectants due to its cell wall containing a large amount of lipids and forming capsules [15]. The significant decrease in the relative abundance of these groups of bacteria indicates that disinfection with tea polyphenols inhibited the growth of common Gram-negative pathogenic bacteria and had an obvious controlling effect on Mycobacterium with strong resistance to disinfection.

\subsection{Analysis of Risk Microorganisms and Their Virulence Factors through Disinfection with Tea Polyphenols}

The risk of diseases in drinking water is diverse, among which pathogenic bacteria are easily the cause of infectious diseases, which is the most common health risk in drinking water [40]. Its gene products that can cause colonization, reproduction and disease in the host environment are called virulence factors (VFS), which is the key to the virulence of pathogenic bacteria, in addition to their survival in the host and host disease [41].

The study uses the BLAST similarity comparison search method to build a BLAST analysis of the MvirDB protein database. This analysis on the MvirDB protein database showed that 247 virulence factors were detected in raw water and 191 were detected in 5TP. The diversity of virulence factors detected was reduced by 56, as shown in Table 5. After disinfection with tea polyphenols, the absolute abundance of various virulence factors decreased, and the total absolute abundance decreased by $51 \%$. As can be seen in Table 5, the main virulence factors carried by pathogenic bacteria changed little after tea polyphenols disinfection, but the abundance of virulence factor genes (readings) decreased significantly, ranging from $32 \%$ to $67 \%$. Among them, the absolute abundance of virulence factors closely related to the iron uptake system and the adhesion of pathogenic bacteria decreased the most, mainly, the virulence factor Pyoverdine and Type IV pili (Pseudomonas aeruginosa PAO1 and Klebsiella pneumoniae subsp. Pneumoniae NTUH-K2044). They play an important regulatory role in the release of virulence factors, forming biofilms and showing good adhesion [42]. The absolute abundance of the virulence factor CdpA [43] (Burkholderia pseudomallei K96243), which is closely related to the signal transducer system, was also significantly reduced. It regulates intracellular levels of C-DI-GMP (cyclic dimeric guanosine monophosphate) and affects a variety of phenotypes, such as flagella synthesis, bacterial movement, exopolysaccharide production, interbacterial aggregation, biofilm formation, cytotoxicity and host cell invasion [44]. 
Table 5. Gene abundance and relative abundance of virulence factors of major pathogens.

\begin{tabular}{|c|c|c|c|}
\hline \multirow[t]{2}{*}{ Main Pathogenic Bacteria } & \multirow[t]{2}{*}{ Virulence Factors } & \multicolumn{2}{|c|}{$\begin{array}{l}\text { Absolute Abundance of } \\
\text { Virulence Factor Genes/ } \\
\text { (Reads) }\end{array}$} \\
\hline & & Raw & $5 \mathrm{TP}$ \\
\hline $\begin{array}{l}\text { Pseudomonas aeruginosa } \\
\text { PAO1 }\end{array}$ & $\begin{array}{l}\text { Alginate, Alkaline protease, Deoxyhexose linking sugar, Flagella, } \\
\text { HSI-I, LasB, LPS, Phenazines biosynthesis, Pyochelin, Pyocyanin, } \\
\text { pyoverdine, Rhamnolipid, TTSS, Type IV pili, xcp secretion system }\end{array}$ & 85,597 & 40,839 \\
\hline $\begin{array}{l}\text { Burkholderia pseudomallei } \\
\text { K96243 }\end{array}$ & $\begin{array}{c}\text { BimA, BoaA, BoaB, Bsa T3SS, Capsule I, CdpA, Flagella, } \\
\text { Quorum-sensing, T6SS-1, Type IV pili }\end{array}$ & 35,117 & 21,247 \\
\hline $\begin{array}{l}\text { Mycobacterium tuberculosis } \\
\text { H37Rv }\end{array}$ & $\begin{array}{l}\text { Antigen 85, Erp, ESX-1, ESX-3, ESX-5, FadD33, HbhA, IdeR, } \\
\text { Isocitrate lyase, LipF, MgtC, Mycobactin, PhoP/R, RegX3, RelA }\end{array}$ & 26,086 & 14,371 \\
\hline Neisseria meningitidis MC58 & $\begin{array}{c}\text { Capsule, FarAB, FbpABC, HmbR, IgA1 protease, KatA, Lbp, } \\
\text { MntABC, MsrAB, MtrCDE, Porin, RecN, Type IV pili }\end{array}$ & 32,460 & 16,823 \\
\hline $\begin{array}{l}\text { Legionella pneumophila } \\
\text { subsp. pneumophila str. } \\
\text { Philadelphia } 1\end{array}$ & $\begin{array}{c}\text { T2SS, CcmC, Cytochrome c maturation (ccm) locus, Dot/Icm, enh } \\
\text { loci, FeoAB, Flagella, Hsp60, IraAB, Iron acquisition/assimilation } \\
\text { locus, KatAB, Legiobactin, LigA, lsp, Mip, Pht, Polar flagella, RtxA, } \\
\text { SodB, SodC, type IV pili }\end{array}$ & 22,205 & 7668 \\
\hline $\begin{array}{l}\text { Haemophilus influenzae Rd } \\
\qquad \text { KW20 }\end{array}$ & Hgp, HitABC, HxuABC, IgA1 protease, LOS, P5 protein & 18,942 & 6715 \\
\hline Escherichia coli CFT073 & $\begin{array}{c}\text { Aerobactin, Chu, Enterobactin, F1C fimbriae, Hemolysin, IroN, P } \\
\text { fimbriae, Salmochelin, TcpC, Type } 1 \text { fimbriae }\end{array}$ & 14,318 & 5076 \\
\hline $\begin{array}{l}\text { Aeromonas hydrophila subsp. } \\
\text { hydrophila ATCC } 7966\end{array}$ & $\begin{array}{c}\text { Amonabactin, exe, Flp type IV pili, Hemolysin III, Hemolysin, } \\
\text { HlyA, Mannose-sensitive hemagglutinin (Msh) pilus, type IV pili, } \\
\text { Polar flagella, T6SS, Tap type IV pili, RTX, TH, Type I fimbriae, } \\
\text { VgrG1 }\end{array}$ & 18,166 & 10,228 \\
\hline $\begin{array}{l}\text { Salmonella enterica subsp. } \\
\text { enterica serovar Typhimurium } \\
\text { str. LT2 }\end{array}$ & $\begin{array}{l}\text { Agf, Bcf, AGF, Lpf, MgtBC, MisL, Rck, ShdA, SodCI, Spv, TTSS } \\
\text { (SPI-1 encode), TTSS (SPI-2 encode), Type } 1 \text { fimbriae }\end{array}$ & 9166 & 3014 \\
\hline Bordetella pertussis Tohama I & Brk, Cya, FHA, Fimbriae, LPS, Pertactin, Ptx, TcfA, TTSS & 10,806 & 5145 \\
\hline $\begin{array}{l}\text { Streptococcus agalactiae } \\
2603 \mathrm{~V} / \mathrm{R}\end{array}$ & Beta-hemolysin/cytolysin, Capsule, Lmb & 11,946 & 6748 \\
\hline $\begin{array}{l}\text { Acinetobacter baumannii } \\
\text { ACICU }\end{array}$ & $\begin{array}{c}\text { Bap, BfmRS, Csu fimbriae, Phospholipase C, PNAG, Quorom } \\
\text { sensing }\end{array}$ & 10,147 & 5165 \\
\hline $\begin{array}{l}\text { Klebsiella pneumoniae subsp. } \\
\text { pneumoniae NTUH-K2044 }\end{array}$ & Salmochelin, type 3 fimbriae (biofilm formation), yersiniabactin & 14,992 & 10,062 \\
\hline $\begin{array}{l}\text { Campylobacter jejuni subsp. } \\
\text { jejuni NCTC } 11168\end{array}$ & $\begin{array}{l}\text { CadF, Capsule, Capsule biosynthesis and transport, Flagella, LOS, } \\
\text { PEB1, Pse5Ac7Ac, Pse5Ac7Am, Pse8OAc, Pse5Am7AcGlnAc }\end{array}$ & 9462 & 3953 \\
\hline else & - & 55,039 & 26,638 \\
\hline
\end{tabular}

Virulence factors are important pathogenic genes encoded and transported by the isle of pathogenicity (PAI), which can adapt to a specific growth environment and meet the needs of life through horizontal microbial transfer along with PAI [45]. Huang [46] found that the diversity and abundance of bacterial virulence factors increased after disinfection with chlorine. However, the disinfection with tea polyphenols is different. After disinfection with tea polyphenols, the abundance of genes for major virulence factors significantly decreases, which is also the reason why tea polyphenols disinfection is selective, i.e., tea polyphenols can inhibit the growth of harmful bacteria common to the human body and promote the growth of beneficial bacteria [25]. 


\section{Conclusions}

This paper mainly explores the disinfection effect of tea polyphenols as a disinfectant in the treatment of ultrafiltration effluent, and the characteristics and changes of microbial community structure and community function in the water after disinfection. The disinfection effect of tea polyphenols in ultrafiltration effluent was discussed from the control of microbial regrowth and disinfectant attenuation. At the same time, through the study of macrogenomics of microorganisms in water after tea polyphenol disinfection, the microbial community structure, community functional characteristics, and changes after disinfection were discussed, and the principle of tea polyphenol disinfection was revealed. The conclusions are as follows:

(1) The main function of the disinfection with tea polyphenols in the treatment of ultrafiltration effluent is to inhibit bacterial growth. The recommended dosage is $5.0 \mathrm{mg} / \mathrm{L}$, which can meet the total number of colonies requirements in the drinking water quality standards within $48 \mathrm{~h}$, and meet the microbial control needs of urban pipe networks of different sizes;

(2) When the dosage of tea polyphenols is $5-10 \mathrm{mg} / \mathrm{L}$, the attenuation of tea polyphenols is in accordance with the kinetic equation of the second order reaction. The lower the initial concentration and the higher the reaction temperature, the faster the attenuation of tea polyphenols. For water supply systems using surface water as a source, it is suggested to appropriately increase the amount of polyphenols in tea in summer;

(3) Disinfection with tea polyphenols will reduce microbial diversity in the water and change the structure of the flora. Disinfection with tea polyphenols inhibited the growth of common Gram-negative conditional pathogens, especially Mycobacterium with strong resistance to disinfection. The increase in the relative abundance of Janthinobacterium strengthened the bactericidal capacity of tea polyphenols;

(4) Disinfection with tea polyphenols reduced the diversity and abundance of virulence factor genes of pathogenic bacteria. Among which, the abundance of virulence factors, closely related to the iron uptake and adhesion system, decreased, followed by the virulence factors that control the signal transduction system. This makes disinfection with tea polyphenols selective, meaning tea polyphenols inhibit the growth of harmful bacteria and promote the growth of beneficial bacteria.

Author Contributions: Conceptualization, T.W. and S.Q.; methodology, T.W.; validation, F.H. and X.T.; writing-original draft preparation, T.W. and S.Q.; writing-review and editing, T.W.; supervision, C.F.; project administration, C.F. All authors have read and agreed to the published version of the manuscript.

Funding: This research received no external funding.

Institutional Review Board Statement: Not applicable.

Informed Consent Statement: Not applicable.

Acknowledgments: This research is funded by National Natural Science Foundation of China (51678026), Open Research Fund Program of Key Laboratory of Urban Stormwater System and Water Environment (Beijing University of Civil Engineering and Architecture), Ministry of Education (2020) and Beijing University of Civil Engineering Postgraduate Innovation Project (PG2021047).

Conflicts of Interest: The authors declare no conflict of interest.

\section{References}

1. Ribeiro, M.A.; Cruz, J.M.; Montagnolli, R.N.; Bidoia, E.D.; Lopes, P.R.M. Photocatalytic and photoelectrochemical inactivation of Escherichia coli and Staphylococcus aureus. Water Sci. Technol. 2015, 15, 107-113. [CrossRef]

2. Ngwenya, N.; Ncube, E.J.; Parsons, J. Recent advances in drinking water disinfection: Successes and challenges. Rev. Environ. Contam. Toxicol. 2013, 222, 111-170. [PubMed]

3. Bekink, M.J.; Nozaic, D.J. Assessment of a chlorine dioxide proprietary product for water and wastewater disinfection. Water SA 2013, 39, 375-378. [CrossRef] 
4. Yang, X.; Guo, W.; Lee, W. Formation of disinfection byproducts upon chlorine dioxide preoxidation followed by chlorination or chloramination of natural organic matter. Chemosphere 2013, 91, 1477-1485. [CrossRef]

5. Zhu, Y.; Wang, H.; Li, X.; Hu, C.; Yang, M.; Qu, J. Characterization of biofilm and corrosion of cast iron pipes in drinking water distribution system with UV/Cl2 disinfection. Water Res. 2014, 60, 174-181. [CrossRef]

6. Lin, T.; Cai, B.; Chen, W. Limnoithona sinensis as refuge for bacteria: Protection from UV radiation and chlorine disinfection in drinking water treatment. Can. J. Microbiol. 2013, 60, 745-752. [CrossRef] [PubMed]

7. Liu, M.; Zhang, B.; Luo, C.; Song, Y.; Xing, L.; Kong, J. Research progress on formation and control of bromate in ozone activated carbon process. Appl. Chem. Ind. 2020, 49, 1786-1789.

8. Xie, H.; Feng, C.; Huang, H. Study on disinfection effect and disinfection sustainability of three plant polyphenols. Technol. Water Treat. 2015, 8, 72-75.

9. Feng, C.; Xie, H.; Wang, X.; Yang, T.; Huang, H. Study and Exploration of Drinking Water Disinfection Using Tea Polyphenols. Environ. Sci. Technol. 2016, 39, 69-73.

10. Fu, W.; Sun, L. Exploratory study on the bactericidal and softening properties of plant polyphenols. Water Wastewater Eng. 2006, $32,51-55$.

11. Institute of Environmental and Health-Related Product Safety; Chinese Center for Disease Control and Prevention; National Standardization Administration of China. Sanitary Standards for Domestic Drinking Water: GB 5749-2006; Standards Press of China: Beijing, China, 2007.

12. Zheng, H.; Yu, Y.; Fei, J.; Chen, X.; Ding, Z. Exploration of water quality sanitation standards for emergency water supply in case of sudden drinking water contamination. J. Environ. Occup. Med. 2016, 33, 81-84.

13. Yang, T. Characterization of Water Quality in a Combined Ultraviolet-Tea Polyphenols Disinfection System for Pipe Networks; Beijing University of Civil Engineering and Architecture: Beijing, China, 2017.

14. Guo, Z. Combined Ozone-Tea Polyphenol Disinfection Effect and Microbial Characteristics of Pipeline Network; Beijing University of Civil Engineering and Architecture: Beijing, China, 2019.

15. Liu, X.; Song, C.; Feng, C.; Tian, M.; Ji, H.; Zhang, X.; Ding, Z. Microbial characterization of combined ultraviolet-tea polyphenols/sodium hypochlorite disinfection pipeline network. Chin. J. Environ. Eng. 2019, 13, 616-623.

16. Li, G.; Liang, H.; Qu, F. A historical perspective on the development of biopathogenic risk control technologies for urban drinking water. Water Wastewater Eng. 2013, 39, 1-5.

17. Li, G.; Qu, F. Urban drinking water purification ultrafiltration water plant design some new ideas. Water Wastewater Eng. 2015, 000(001), 1-3.

18. Huang, J.; Yang, Y.; Li, X.; Xi, L.; Li, G. Decontamination characteristics and chlorine disinfection efficiency of different pretreatment/ultrafiltration processes. China Water Wastewater 2012, 28, 31-34, 39 .

19. Botes, J.E.; Jacobs, E.E.; Brads Haw, S.M. Long-term evaluation of a UF pilot plant for potable water production. Desalination 1998, 115, 229-238. [CrossRef]

20. Park, S.K.; Jiang, Y.H. Assessment of the extent of bacterial growth in reverse osmosis system for improving drinking water quality. J. Environ. Sci. Health Part A Toxic/Hazard. Subst. Environ. Eng. 2010, 45, 968-977. [CrossRef]

21. Ho, L.; Braun, K.; Fabris, R.; Hoefel, D.; Morran, J.; Monis, P.; Drikas, M. Comparison of drinking water treatment process streams for optimal bacteriological water quality. Water Res. 2012, 46, 3934-3942. [CrossRef]

22. Liu, G.; Lut, M.C.; Verberk, J.Q.J.C.; Van Dijk, J.C. A comparison of additional treatment processes to limit particle accumulation and microbial growth during drinking water distribution. Water Res. 2013, 47, 2719-2728. [CrossRef] [PubMed]

23. Miller, R.R.; Montoya, V.; Gardy, J.L.; Patrick, D.M.; Tang, P. Metagenomics for pathogen detection in public health. Genome Res. 2013, 5, 81. [CrossRef] [PubMed]

24. Deng, W.; Wang, Y.; Liu, Z.; Cheng, H.; Xue, Y. HemI: A Toolkit for Illustrating Heatmaps. PLoS ONE 2014, 9, e111988. [CrossRef] [PubMed]

25. Wang, L.; Xu, Q.; Xu, S.; Zhang, W.; Huang, Y. Progress of research on the effect of tea polyphenols on microbial growth. Mod. Food Sci. Technol. 2013, 29, 1737-1741.

26. Wu, X. Study on Disinfection Properties of Tea Polyphenols and Mechanism of Action on Escherichia coli; Beijing University of Civil Engineering and Architecture: Beijing, China, 2018.

27. Li, W.; Wang, W.; Wang, W. Progress in the study of oxidative polymerization mechanism of tea polyphenols. J. Jinan Univ. (Nat. Sci. Med. Ed.) 2016, 37, 193-200.

28. Zhang, Y.; Liu, W.T. The application of molecular tools to study the drinking water microbiome-Current understanding and future needs. Crit. Rev. Environ. Sci. Technol. 2019, 49, 1188-1235. [CrossRef]

29. Gomez-Alvarez, V.; Revetta, R.P.; Santo Domingo, J.W. Metagenomic Analyses of Drinking Water Receiving Different Disinfection Treatments. Appl. Environ. Microbiol. 2012, 78, 6095-6102. [CrossRef] [PubMed]

30. Bautista-De Los Santos, Q.M.; Schroeder, J.L.; Sevillano-Rivera, M.C.; Sungthong, R.; Ijaz, U.Z.; Sloan, W.T.; Pinto, A.J. Emerging investigators series: Microbial communities in full-scale drinking water distribution systems-A meta-analysis. Environ. Sci. Water Res. Technol. 2016, 2, 631-644. [CrossRef]

31. Chao, Y.; Ma, L.; Yang, Y.; Ju, F.; Zhang, X.-X.; Wu, W.; Zhang, T. Metagenomic analysis reveals significant changes of microbial compositions and protective functions during drinking water treatment. Sci. Rep. 2013, 3, 3550. [CrossRef] 
32. Sun, H.; Shi, B.; Bai, Y.; Wang, D. Bacterial community of biofilms developed under different water supply conditions in a distribution system. Sci. Total. Environ. 2014, 472, 99-107. [CrossRef]

33. Yan, Z. Microbial Community Dynamics and Assembly: Drinking Water Treatment and Distribution; The University of Tennessee: Knoxville, TN, USA, 2012.

34. Gulati, P.; Ghosh, M. Biofilm forming ability of Sphingomonas paucimobilis isolated from community drinking water systems on plumbing materials used in water distribution. J. Water Health 2017, 15, 942-954. [CrossRef]

35. de Vries, H.J.; Beyer, F.; Jarzembowska, M.; Lipińska, J.; van den Brink, P.; Zwijnenburg, A.; Timmers, P.H.A.; Stams, A.J.M.; Plugge, C.M. Isolation and characterization of Sphingomonadaceae from fouled membranes. Biofilms Microbiomes $2019,5,6$. [CrossRef]

36. Baldani, J.I.; Rouws, L.; Cruz, L.M.; Olivares, F.L.; Hartmann, A. The Prokaryotes: The Family Oxalobacteraceae; Springer: Berlin/Heidelberg, Germany, 2014.

37. Durán, M.; Ponezi, A.N.; Faljoni-Alario, A.; Teixeira, M.F.S.; Justo, G.Z.; Durán, N. Potential applications of violacein: A microbial pigment. Med. Chem. Res. 2012, 21, 1524-1532. [CrossRef]

38. Durán, N.; Justo, G.Z.; Durán, M.; Brocchi, M.; Cordi, L.; Tasic, L.; Castro, G.R.; Nakazato, G. Advances in Chromobacterium violaceum and properties of violacein-Its main secondary metabolite: A review. Biotechnol. Adv. 2016, 34, 1030-1045. [CrossRef]

39. Tang, F.; Huang, S.H. Bacteriological Testing; People's Medical Publishing House (PMPH): Beijing, China, $2015 ;$ pp. 63-145.

40. Organisation, W.H.; Staff, W.H.O. Guidelines for Drinking-Water Quality, 4th ed.; World Health Organization: Geneva, Switzerland, 2011.

41. Zheng, D. Design and Construction of a Data Analysis Platform for Virulence Factors of Pathogenic Bacteria; Peking Union Medical College: Beijing, China, 2017.

42. Yu, S.; Ma, L. Advances in iron uptake and biofilm formation in Pseudomonas aeruginosa. Chin. J. Biotechnol. 2017, 33, 1489-1512.

43. Lee, H.S.; Gu, F.; Ching, S.M.; Lam, Y.; Chua, K.L. CdpA Is a Burkholderia pseudomallei Cyclic di-GMP Phosphodiesterase Involved in Autoaggregation, Flagellum Synthesis, Motility, Biofilm Formation, Cell Invasion, and Cytotoxicity. Infect. Immun. 2010, 78, 1832-1840. [CrossRef] [PubMed]

44. Hengge, R. Principles of c-di-GMP signalling in bacteria. Nat. Rev. Microbiol. 2009, 7, 263-273. [CrossRef] [PubMed]

45. Niu, C. Study on Virulence of Unknown Bacterial Pathogens, Recombinant Screening System; Academy of Military Medical Sciences: Beijing, China, 2010.

46. Huang, K.; Zhang, X.X.; Shi, P.; Wu, B.; Ren, H. A comprehensive insight into bacterial virulence in drinking water using 454 pyrosequencing and Illumina high-throughput sequencing. Ecotoxicol. Environ. Saf. 2014, 109, 15-21. [CrossRef] [PubMed] 